\title{
MALACOFAUNA NA GRUTA DA PESCARIA, IPORANGA, SP
}

\author{
Percy Corrêa VIEIRA \\ Luiz Ricardo Lopes de SIMONE
}

Incursões realizadas na Gruta da Pescaria, localizada no Parque Estadual Turístico do Alto Ribeira (PETAR), no Município de Iporanga, $\mathrm{SP}$, resultaram na coleta de conchas de moluscos, cujas espécies os autores assim identificam: Superfamília Strophocheiloidea

Família Megalobulimidae

Megalobulimus yporanganus Thering \& Pilsbry, 1901

Megalobulimus klappenbachi Leme, 1964

Megalobulimus gummatus (Hidalgo, 1870)

Família Strophocheilidae

Mirinaba jaussaudi (Morretes, 1934).

O processo de fossilização é o da incrustação, que se apresenta em vários graus, sendo que muitas conchas já se encontram englobadas pelo travertino em formação na gruta.

É aqui deduzido que os espécimes coletados não viveram em cavernas, pois, à semelhança dos atuais, dependiam de vegetação autótrofa para a alimentação, indo ocorrer neste local através de transporte "post mortem" pelo Rio da Pescaria, que passa pelo interior da gruta, onde perde energia. Há uma hipótese muito controvertida, a qual afirma que esses animais ingressariam em cavernas para se alimentarem de carbonato de cálcio para a construção das conchas.

Os autores supõem tratar-se de material holocênico, já que alguns espécimes conservam a coloração e até o perióstraco além de se asse- melharem com espécimes viventes, assunto que talvez só possa ser decidido através de datação radiométrica.

É interessante notar que Thaumastus magnificus othoni Maury, 1935, subespécie encontrada no Município de Iporanga em blocos carbonáticos tidos como pleistocênicos, bem como Megalobulimus oblongus (Müller, 1774), a mais comum espécie assinalada nas grutas de Lagoa Santa, Minas Gerais, não foram achadas na Gruta da Pescaria, embora isso pudesse ser esperado.

Convém lembrar que $M$. yporanganus foi relatado por MAURY (1935) para o Pleistoceno com o nome de Strophocheilus ovatus iguapensis, em grutas de Iporanga.

A presente nota objetiva divulgar pela primeira vez o encontro dessa malacofauna em gruta (com exceção de $M$. yporanganus), indicando o processo de fossilização e sugerindo que sua presença deve-se a transporte, já que o ecossistema espélico não é adequado à vida desses animais.

Estudos posteriores poderão estabelecer comparações com malacofaunas existentes em outras grutas ou em meios externos, assim como a correta idade da aqui divulgada.

Manuscrito recebido em janeiro de 89

Endereço dos autores:

- Percy Corrêa Vieira - Instituto Geológico - SMA - Caixa Postal 8772 - 01051 - São Paulo, SP - Brasil.

- Luiz Ricardo Lopes de Simone - Rua Conselheiro Cotegipe, 930 - 03058 - São Paulo, SP - Brasil. 